\title{
Aurantimonas frigidaquae sp. nov., isolated from a water-cooling system
}

\author{
Mi Sun Kim, ${ }^{1}$ Kieu Thi Quynh Hoa, ${ }^{2,3}$ Keun Sik Baik, ${ }^{1}$ Seong Chan Park ${ }^{1}$ \\ and Chi Nam Seong ${ }^{1}$
}

Correspondence

Chi Nam Seong

scnu@scnu.ac.kr

\author{
${ }^{1}$ Department of Biology, College of Natural Sciences, Sunchon National University, Suncheon \\ 540-742, Republic of Korea \\ ${ }^{2}$ Institute of Water Quality Control and Waste Management, Technical University of Munich, \\ Am Coulombwall, D-85748 Garching, Munich, Germany \\ ${ }^{3}$ Department of Petroleum Microbiology, Institute of Biotechnology, Vietnamese Academy of \\ Science and Technology, No. 18, Hoang Quoc Viet, Cau Giay District, Hanoi, Vietnam
}

\begin{abstract}
A motile, short rod-shaped and yellow-pigmented bacterium, designated strain $\mathrm{CW}^{\top}$, was isolated from a water-cooling system at Gwangyang, Republic of Korea. Cells were Gram-negative, facultatively anaerobic and catalase- and oxidase-positive. The major fatty acids were $\mathrm{C}_{18: 1} \omega 7 c(64.7 \%)$ and $\mathrm{C}_{16: 0}(14.1 \%)$. The DNA G+C content was $63.9 \mathrm{~mol} \%$. A phylogenetic tree based on $16 \mathrm{~S}$ rRNA gene sequence comparison showed that strain $\mathrm{CW}^{\top}$ clustered within the Aurantimonas lineage and is closely related to the type strains of Aurantimonas altamirensis (98.5\% sequence similarity) and Aurantimonas coralicida (95.7\%). The phenotypic characteristics and DNA-DNA hybridization data indicate that strain $\mathrm{CW} 5^{\top}$ could be distinguished from the phylogenetic relatives $A$. altamirensis and $A$. coralicida. On the basis of the evidence presented in this study, strain $C W 5^{\top}$ represents a novel species of the genus Aurantimonas, for which the name Aurantimonas frigidaquae sp. nov. is proposed. The type strain is $\mathrm{CW5}^{\top}\left(=\mathrm{KCTC} 12893^{\top}=\mathrm{JCM} 14755^{\top}\right)$.
\end{abstract}

The genera Aurantimonas (Denner et al., 2003), Fulvimarina (Cho \& Giovannoni, 2003) and Martelella (Rivas et al., 2005) constitute the three members of the recently described family 'Aurantimonadaceae' within the order Rhizobiales and take up a distinct phylogenetic position separable from the other families within the order Rhizobiales. The genus Aurantimonas was first described by Denner et al. (2003) and, at the time of writing, the genus comprises the two species Aurantimonas coralicida and Aurantimonas altamirensis, respectively isolated from diseased coral (Dichocoenia stokesi) (Denner et al., 2003) and subterranean soil (Jurado et al., 2006) (http:// www.bacterio.cict.fr/a/aurantimonas.html).

In the course of our study on the microbial diversity of a water-cooling system, a yellow-pigmented bacterium, designated $\mathrm{CW}^{\mathrm{T}}$, was isolated and was the subject of a taxonomic investigation. On the basis of evidence from a polyphasic study, strain $\mathrm{CW} 5^{\mathrm{T}}$ represents a novel species in the genus Aurantimonas.

Strain $C W 5^{\mathrm{T}}$ was isolated from a cooled water sample from an oxygen-producing plant in the Republic of Korea during February 2005 using the standard dilution-plating

The GenBank/EMBL/DDBJ accession number for the 16S rRNA gene sequence of strain $C W 5^{\top}$ is EF373540. technique. Isolation was achieved using plate count agar (PCA; Difco) at $25{ }^{\circ} \mathrm{C}$ for 7 days. The isolate was routinely cultured on tryptic soy agar (TSA; Difco) and maintained as a glycerol suspension $(20 \%, w / v)$ at $-80{ }^{\circ} \mathrm{C}$.

Bacterial DNA preparation, PCR amplification and sequencing of the $16 \mathrm{~S}$ rRNA gene were carried out as described previously (Chun \& Goodfellow, 1995). The resultant sequence of strain $\mathrm{CW}^{\mathrm{T}}$ (1378 nt) was aligned manually against sequences obtained from the GenBank database. Phylogenetic trees were inferred from the regions available for all sequences (positions 22-1450; Escherichia coli numbering system) using the Fitch-Margoliash (Fitch \& Margoliash, 1967) and neighbour-joining (Saitou \& Nei, 1987) methods. Evolutionary distance matrices were generated according to Jukes \& Cantor (1969). The resultant neighbour-joining tree topology was evaluated by means of bootstrap analyses (Felsenstein, 1985) based on 1000 resamplings. Alignment and phylogenetic analyses were carried out using the jPHYDIT program and PAUP 4.0 (Swofford, 1998), as described previously (Chun et al., 2000).

Preliminary sequence comparison with $16 \mathrm{~S}$ rRNA gene sequences held in GenBank indicated that our isolate was related closely to the genus Aurantimonas. The newly determined sequence was then aligned manually against 
representatives of the genus Aurantimonas. Strain $\mathrm{CW} 5^{\mathrm{T}}$ showed the highest 16S rRNA gene sequence similarity with the type strain of $A$. altamirensis $(98.5 \%)$ followed by the type strain of A. coralicida (95.7\%). To elucidate the phylogenetic relationship between the novel isolate and other species of the genus Aurantimonas, phylogenetic trees were constructed by using two different tree-making algorithms. The neighbour-joining tree (Fig. 1) showed that strain $\mathrm{CW}^{\mathrm{T}}$ was closely related to the type strain of $A$. altamirensis with $99 \%$ bootstrap support.

Growth on various standard bacteriological media was tested by using nutrient agar (NA), tryptic soy agar (TSA), R2A agar, MacConkey agar and marine agar (MA) (all from Difco) according to the manufacturer's instructions. Cells of strain $\mathrm{CW} 5^{\mathrm{T}}$ grown on TSA at $25{ }^{\circ} \mathrm{C}$ for $3-7$ days were used for physiological and biochemical tests. Motility was examined by observing cells grown in wet mounts using phase-contrast microscopy (TMS-F; Nikon). Growth at various $\mathrm{NaCl}$ concentrations $(0-10 \%, \mathrm{w} / \mathrm{v}$, in increments of $1.0 \%$ ) was investigated in tryptic soy broth (TSB) prepared according to the formula of the Difco medium except that no $\mathrm{NaCl}$ was used. The $\mathrm{pH}$ range for growth was determined in TSB (Difco) that was adjusted to various $\mathrm{pH}$ values ( $\mathrm{pH} 3-12$, in increments of $1 \mathrm{pH}$ unit) by the addition of $\mathrm{HCl}$ and $\mathrm{NaOH}$. Growth temperature $\left(4-42{ }^{\circ} \mathrm{C}\right)$ and growth in an anaerobic chamber $\left(\mathrm{CO}_{2} / \mathrm{H}_{2} /\right.$ $\mathrm{N}_{2}, 10: 10: 80$; Sheldon Manufacturing) were checked using TSA, using incubation times of up to 1 week. Catalase and oxidase activities were determined using 3\% (v/v) hydrogen peroxide and Kovacs' reagent (Kovacs, 1956), respectively. Acid production from sugars was tested as described by Yamaguchi \& Yokoe (2000). Nitrate reduction was tested on nitrate broth containing $0.2 \%$ $\mathrm{KNO}_{3}$ (Skerman, 1967). Citrate utilization was tested on Simmons' citrate agar (Sigma). Indole production was determined with Kovacs' indole reagent in $1 \%$ tryptone broth. $\mathrm{H}_{2} \mathrm{~S}$ production was determined on Kligler iron agar (Difco). L-Phenylalanine deamination was examined with the method of Richard \& Kiredjian (1995). Urease activity was tested on Christensen's medium (Oxoid). Hydrolysis of casein, starch and L-tyrosine was examined on NA containing $2 \%$ skimmed milk, $0.2 \%$ soluble starch and $0.5 \%$ Ltyrosine (Barrow \& Feltham, 1993), respectively. Precipitation on egg yolk was determined on NA containing $10 \%$ egg yolk (Barrow \& Feltham, 1993). DNase activity was determined with DNase test agar (Difco). Methyl red and Voges-Proskauer tests were analysed as described by Smibert \& Krieg (1994). The absorption spectrum of pigment extracted by ethanol (Gosink et al., 1998) was analysed using an Ultrospec 2100 pro UV/visible spectrophotometer (Amersham Biosciences). The presence of flexirubin-type pigments was examined as described by Bernardet et al. (2002). Other physiological and biochemical tests were performed using API 20E, API 20NE and API $50 \mathrm{CH}$ strips (bioMérieux). Enzyme activities were tested using the API ZYM kit (bioMerieux) following the manufacturer's instructions. Antibiotic resistance was determined with the disc diffusion method using commercial antibiotic-impregnated discs (BBL Becton Dickinson). The results were interpreted according to the guidelines set forth by the CLSI (2003) (formerly the NCCLS).

Cells of strain $\mathrm{CW}^{\mathrm{T}}$ were facultatively anaerobic, Gramnegative, motile, short rods. Colonies grown on TSA plates for 5 days at $25{ }^{\circ} \mathrm{C}$ were circular, convex with entire margins, smooth, opaque, yellow in colour and approximately $3.0 \mathrm{~mm}$ in diameter. The novel strain grew well on TSA, PCA, R2A and NA, but grew weakly on MA. On TSA, strain $\mathrm{CW} 5^{\mathrm{T}}$ was able to grow at $15-37{ }^{\circ} \mathrm{C}$, but not at $42{ }^{\circ} \mathrm{C}$. Detailed results of physiological and biochemical analyses are given in Table 1 and the species description. Pigment extracts of strain $\mathrm{CW}^{\mathrm{T}}$ showed an absorption maximum at $450 \mathrm{~nm}$ and a shoulder at $477 \mathrm{~nm}$. Flexirubin-type pigments were absent. It is evident from Table 1 that there are several phenotypic characters that readily separate strain $\mathrm{CW}^{\mathrm{T}}$ from the phylogenetically related species $A$. coralicida and A. altamirensis.

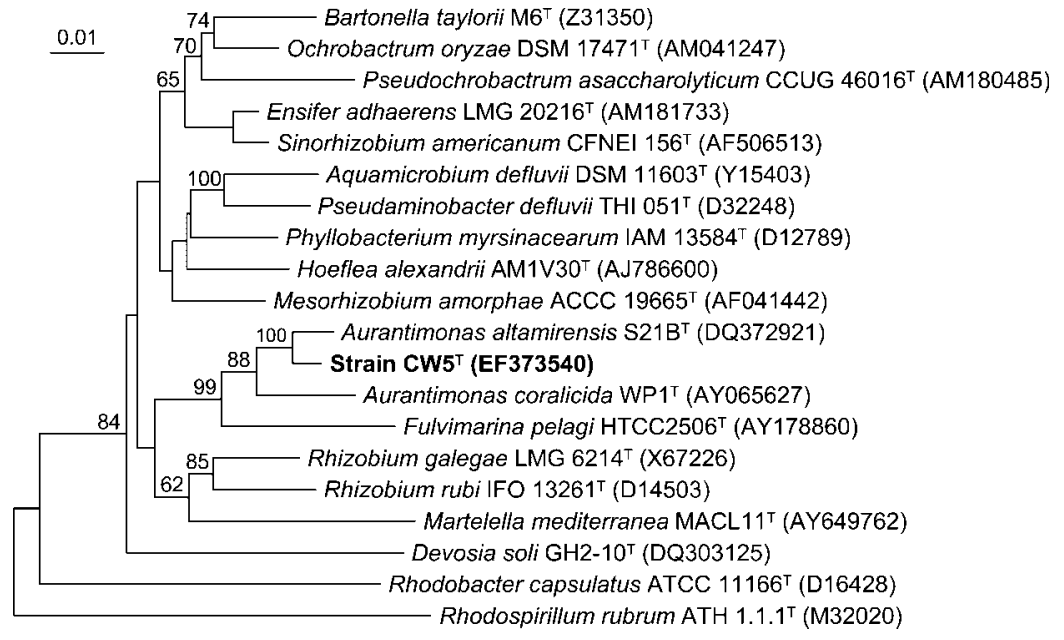

Fig. 1. Neighbour-joining tree based on nearly complete 16S rRNA gene sequences showing relationships between strain $\mathrm{CW} 5^{\top}$, members of the genus Aurantimonas and related members of the order Rhizobiales. Percentages at nodes are levels of bootstrap support based on a neighbour-joining analyses of 1000 resampled datasets. The sequence of Rhodospirillum rubrum ATH 1.1.1 ${ }^{\top}$ was used as an outgroup. Bar, 0.01 substitutions per nucleotide position. 
Table 1. Characteristics that differentiate strain $\mathrm{CW} 5^{\top}$ from other Aurantimonas species

Data for A. coralicida DSM $14790^{\mathrm{T}}$ and A. altamirensis LMG $23375^{\mathrm{T}}$ are from Denner et al. (2003) and Jurado et al. (2006). All three strains are positive for catalase, oxidase, urease, esterase (C4), esterase lipase (C8), acid phosphatase, leucine arylamidase and utilization of glucose, malate, L-arabinose, D-xylose, galactose and mannose. All three strains are negative for Gram stain, sporulation, hydrolysis of gelatin, lipase (C14), cystine arylamidase, $\alpha$-chymotrypsin, $N$-acetyl- $\beta$-glucosaminidase, $\alpha$-fucosidase, $\alpha$-glucosidase, $\beta$-glucuronidase, $\alpha$ mannosidase and utilization of adipate, caprate, citrate and phenylacetate. + , Positive; - , negative; w, weakly positive.

\begin{tabular}{|c|c|c|c|}
\hline Characteristic & Strain CW5 ${ }^{\mathrm{T}}$ & 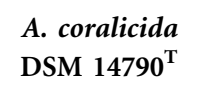 & $\begin{array}{l}\text { A. altamirensis } \\
\text { LMG } 23375^{\mathrm{T}}\end{array}$ \\
\hline Colony colour & Yellow & Golden orange & Yellow \\
\hline Temperature range $\left({ }^{\circ} \mathrm{C}\right)$ & $15-37$ & $4-40$ & $10-40$ \\
\hline Motility & + & + & - \\
\hline Cell shape & Short rod & Rod & Short rod \\
\hline Arginine dihydrolase & - & + & - \\
\hline Acetoin production & + & - & - \\
\hline Nitrate reduction & + & - & - \\
\hline Indole production & + & - & - \\
\hline Hydrolysis of aesculin & + & - & - \\
\hline \multicolumn{4}{|l|}{ Enzyme activity (API ZYM) } \\
\hline Alkaline phosphatase & - & + & + \\
\hline Trypsin & - & - & + \\
\hline Naphthol-AS-BI-phosphohydrolase & - & + & + \\
\hline$\alpha$-Galactosidase & + & - & - \\
\hline$\beta$-Galactosidase & + & - & - \\
\hline$\beta$-Glucosidase & + & - & - \\
\hline \multicolumn{4}{|l|}{ Utilization of (API $50 \mathrm{CH})$ : } \\
\hline L-Arabinose & - & + & + \\
\hline L-Fucose & + & $\mathrm{w}$ & $\mathrm{w}$ \\
\hline Gentiobiose & $\mathrm{w}$ & $\mathrm{w}$ & - \\
\hline Maltose & - & - & + \\
\hline Rhamnose & - & + & + \\
\hline Ribose & $\mathrm{W}$ & + & + \\
\hline L-Xylose & - & + & - \\
\hline Erythritol & + & - & + \\
\hline Mannitol & + & - & + \\
\hline$N$-Acetyl- $\beta$-glucosamine & + & - & + \\
\hline Gluconate & $\mathrm{W}$ & + & + \\
\hline DNA G $+C$ content $(\mathrm{mol} \%)$ & 63.9 & 66.3 & 71.8 \\
\hline
\end{tabular}

Cellular fatty acids of strain CW5 ${ }^{\mathrm{T}}$ were determined under growth conditions identical to those described by Jurado et al. (2006). Cells of strain $\mathrm{CW}^{\mathrm{T}}$ grown on NA supplemented with $2 \%(\mathrm{w} / \mathrm{v}) \mathrm{NaCl}$ for 2 days at $28{ }^{\circ} \mathrm{C}$ were prepared and analysed by GLC according to the instructions of the Microbial Identification System (MIDI, 1999). The $\mathrm{G}+\mathrm{C}$ content of the DNA was determined by using the thermal denaturation method of Marmur \& Doty (1962). The major fatty acids of strain $C W 5^{\mathrm{T}}$ are shown in Table 2 . The predominant fatty acid was 7 -octadecenoic acid $\left(\mathrm{C}_{18: 1} \omega 7 c\right)$, as was the case for $A$. coralicida and $A$. altamirensis. However, strain $\mathrm{CW}^{\mathrm{T}}$ and these species showed significant differences in the content of $\mathrm{C}_{16: 0}$, $\mathrm{C}_{18: 0}$ and $\mathrm{C}_{19: 0} \omega 8 c$ cyclo, as shown in Table 2.

The DNA G + C content of strain $\mathrm{CW}^{\mathrm{T}}$ was $63.9 \mathrm{~mol} \%$, a figure lower than the values reported for the type strains of
A. coralicida (66.3 mol\%; Denner et al., 2003) and A. altamirensis (71.8 mol\%; Jurado et al., 2006).

The taxonomic relationship between strain $\mathrm{CW}^{\mathrm{T}}$ and phylogenetic relatives was further examined using DNADNA hybridization. Genomic relatedness was determined using a membrane filter technique (Seldin \& Dubnau, 1985 ) according to the method described by Baik et al. (2006). DNA relatedness of strain $\mathrm{CW}^{\mathrm{T}}$ with $A$. altamirensis KACC $11704^{\mathrm{T}}$ and A. coralicida KACC $12050^{\mathrm{T}}$ was 45 and $28 \%$, respectively. It is clear from 16S rRNA gene sequence and DNA-DNA hybridization data that strain $\mathrm{CW} 5^{\mathrm{T}}$ represents a novel species in the genus Aurantimonas (Wayne et al., 1987).

In addition, a number of physiological and chemotaxonomic characters clearly distinguish the isolate from other 
Table 2. Fatty acid compositions of strain $\mathrm{CW}^{\top}$ and type strains of other Aurantimonas species

Data for reference strains were obtained from Jurado et al. (2006). Values are percentages of total fatty acids. tr, Trace amount $(<1 \%) ;-$, not detected.

\begin{tabular}{|c|c|c|c|}
\hline Fatty acid & Strain $C W 5^{\mathrm{T}}$ & A. coralicida DSM $14790^{\mathrm{T}}$ & A. altamirensis LMG $23375^{\mathrm{T}}$ \\
\hline$C_{16: 0}$ & 14.1 & $6.2 \pm 0.0$ & $11.3 \pm 0.1$ \\
\hline iso- $\mathrm{C}_{16: 0}$ & - & - & $1.4 \pm 0.0$ \\
\hline $\mathrm{C}_{18: 0}$ & 5.8 & $2.0 \pm 0.0$ & $\operatorname{tr}$ \\
\hline $\mathrm{C}_{18: 0} 3-\mathrm{OH}$ & 1.1 & - & - \\
\hline $\mathrm{C}_{18: 1} 2-\mathrm{OH}$ & 5.6 & $3.2 \pm 0.0$ & $3.5 \pm 0.1$ \\
\hline $\mathrm{C}_{18: 1} \omega 7 c$ & 64.7 & $69.4 \pm 0.0$ & $74.4 \pm 0.2$ \\
\hline $\mathrm{C}_{19: 0} \omega 8 c$ cyclo & 6.5 & $13.2 \pm 0.0$ & - \\
\hline $\mathrm{C}_{20: 1} \omega 7 c$ & - & $\operatorname{tr}$ & - \\
\hline Summed feature $2^{*}$ & 1.4 & - & - \\
\hline Summed feature $3^{*}$ & $\operatorname{tr}$ & - & - \\
\hline
\end{tabular}

${ }^{\star}$ Summed features represent groups of two or three fatty acids that could not be separated by GLC with the MIDI system. Summed feature 2 contained $\mathrm{C}_{14: 0} 3-\mathrm{OH}$ and/or iso- $\mathrm{C}_{16: 1} \mathrm{I}$, and summed feature 3 contained iso- $\mathrm{C}_{15: 0} 2-\mathrm{OH}$ and/or $\mathrm{C}_{16: 1} \omega 7 c$.

phylogenetically related species (Tables 1 and 2). Therefore, strain $\mathrm{CW}^{\mathrm{T}}$ represents a novel species within the genus Aurantimonas, for which the name Aurantimonas frigidaquae sp. nov. is proposed.

\section{Description of Aurantimonas frigidaquae sp. nov.}

Aurantimonas frigidaquae (fri.gi.da'quae. L. adj. frigidus cold; L. fem. n. aqua water; N.L. gen. n. frigidaquae from/of cold water, because the type strain was isolated from a water-cooling system).

Cells are short rods $(0.6-0.8 \times 0.8-1.2 \mu \mathrm{m})$. Gram-negative, motile, facultatively anaerobic and yellow-pigmented bacterium. Grows best on media such as TSA, NA and R2A. Grows on MacConkey medium. Colonies on TSA agar are convex, circular, smooth, opaque with entire margins, approximately $3 \mathrm{~mm}$ in diameter after 5 days at $25{ }^{\circ} \mathrm{C}$ ( $\mathrm{pH} 7)$. Growth occurs in $0-7 \%(\mathrm{w} / \mathrm{v}) \mathrm{NaCl}$ (optimum growth in the absence of $\mathrm{NaCl}$ ). Growth occurs at $\mathrm{pH}$ 5-11 (optimum pH 7) and at $15-37^{\circ} \mathrm{C}$ (optimum $25^{\circ} \mathrm{C}$ ). Oxidase and catalase activities are present, but lysine decarboxylase, ornithine decarboxylase, L-phenylalanine arylamidase and valine arylamidase activities are absent. Aesculin is hydrolysed, but casein, DNA, gelatin, starch, Tween 80 and tyrosine are not. Citrate is not utilized. Acid is produced from $0.5 \%(\mathrm{w} / \mathrm{v})$ glucose, but not from maltose. Negative for methyl red and Voges-Proskauer reactions. No precipitate is formed on egg-yolk agar. Does not produce $\mathrm{H}_{2} \mathrm{~S}$. In API $50 \mathrm{CH}$ tests, acid is produced from cellobiose, D-fucose, fructose, raffinose, sucrose, adonitol, D- and Larabitol, inositol, mannitol, $\mathrm{N}$-acetylglucosamine, amygdalin, arbutin, aesculin and salicin, but not from lactose, melezitose, D-tagatose, dulcitol, glycerol, methyl $\beta$-D-xyloside, methyl $\alpha$-D-mannoside, methyl $\alpha$-D-glucoside, inulin, glycogen, starch, gluconate, 2-ketogluconate or 5-ketogluconate. In the API ZYM gallery, esterase (C4), esterase lipase (C8), leucine arylamidase and acid phosphatase activities are present, but lipase (C14), valine arylamidase, cystine arylamidase, $\alpha$-chymotrypsin, $\beta$-glucuronidase, $\alpha$-glucosidase, $N$-acetyl- $\beta$-glucosaminidase, $\alpha$-mannosidase and $\alpha$-fucosidase activities are absent. Cells are sensitive to ( $\mu \mathrm{g}$ per disc, unless indicated otherwise): ampicillin (10), chloramphenicol (30), erythromycin (15), gentamicin (10), kanamycin (30), nalidixic acid (30), polymyxin B (300 U), streptomycin (10) and tetracycline (30), but resistant to bacitracin (10), penicillin (10 $\mathrm{U}$ ) and vancomycin (30). Other physiological and biochemical characteristics are given in Table 1 . Major fatty acids are $\mathrm{C}_{18: 1} \omega 7 c(64.7 \%)$ and $\mathrm{C}_{16: 0}(14.1 \%)$; the complete fatty acid composition of the type strain is given in Table 2. The DNA G $+\mathrm{C}$ content of the type strain is $63.9 \mathrm{~mol} \%$.

The type strain is $\mathrm{CW}^{\mathrm{T}}\left(=\mathrm{KCTC} 12893^{\mathrm{T}}=\mathrm{JCM} 14755^{\mathrm{T}}\right)$, isolated from a water-cooling system at Gwangyang, Republic of Korea.

\section{Acknowledgements}

This work was supported by the BK21 (the Ministry of Education and Human Resources Development), Republic of Korea. We thank the Korean Agricultural Culture Collection for the gift of strains $A$. altamirensis KACC $11704^{\mathrm{T}}$ and A. coralicida KACC $12050^{\mathrm{T}}$.

\section{References}

Baik, K. S., Park, Y.-D., Seong, C. N., Kim, E. M., Bae, K. S. \& Chun, J. (2006). Glaciecola nitratireducens sp. nov. isolated from seawater. Int $J$ Syst Evol Microbiol 56, 2185-2188.

Barrow, G. I. \& Feltham, R. K. A. (1993). Cowan and Steel's Manual for the Identification of Medical Bacteria, 3rd edn. Cambridge: Cambridge University Press. 
Bernardet, J.-F., Nakagawa, Y. \& Holmes, B. (2002). Proposed minimal standards for describing new taxa of the family Flavobacteriaceae and emended description of the family. Int J Syst Evol Microbiol 52, 1049-1070.

Cho, J. C. \& Giovannoni, S. J. (2003). Fulvimarina pelagi gen. nov., sp. nov., a marine bacterium that forms a deep evolutionary lineage of descent in the order 'Rhizobiales'. Int J Syst Evol Microbiol 53, 1853-1859.

Chun, J. \& Goodfellow, M. (1995). A phylogenetic analysis of the genus Nocardia with $16 \mathrm{~S}$ rRNA gene sequences. Int J Syst Bacteriol 45, 240-245.

Chun, J., Bae, K. S., Moon, E. Y., Jung, S. O., Lee, H. K. \& Kim, S. J. (2000). Nocardiopsis kunsanensis sp. nov., a moderately halophilic actinomycete isolated from a saltern. Int J Syst Evol Microbiol 50, 1909-1913.

CLSI (2003). Performance standards for antimicrobial disk susceptibility tests, 8th edn. Approved Standard M2-A8. Wayne, PA: Clinical Laboratory Standards Institute.

Denner, E. B. M., Smith, G. W., Busse, H.-J., Schumann, P., Narzt, T., Polson, S. W., Lubitz, W. \& Richardson, L. L. (2003). Aurantimonas coralicida gen. nov., sp. nov., the causative agent of white plague type II on Caribbean scleractinian corals. Int J Syst Evol Microbiol 53, 1115-1122.

Felsenstein, J. (1985). Confidence limits on phylogenies: an approach using the bootstrap. Evolution 39, 783-791.

Fitch, W. M. \& Margoliash, E. (1967). Construction of phylogenetic trees. Science 155, 279-284.

Gosink, J. J., Woese, C. R. \& Staley, J. T. (1998). Polaribacter gen. nov., with three new species, $P$. irgensii sp. nov., $P$. franzmannii sp. nov. and $P$. filamentus sp. nov., gas vacuolate polar marine bacteria of the Cytophaga-Flavobacterium-Bacteroides group and reclassification of 'Flectobacillus glomeratus' as Polaribacter glomeratus comb. nov. Int J Syst Bacteriol 48, 223-235.

Jukes, T. H. \& Cantor, C. R. (1969). Evolution of protein molecules. In Mammalian Protein Metabolism, vol. 3, pp. 21-132. Edited by H. N. Munro. New York: Academic Press.

Jurado, V., Gonzalez, J. M., Laiz, L. \& Saiz-Jimenez, C. (2006). Aurantimonas altamirensis sp. nov., a member of the order Rhizobiales isolated from Altamira Cave. Int J Syst Evol Microbiol 56, 2583-2585.
Kovacs, N. (1956). Identification of Pseudomonas pyocyanea by the oxidase reaction. Nature 178, 703.

Marmur, J. \& Doty, P. (1962). Determination of the base composition of deoxyribonucleic acid from its thermal denaturation temperature. $J$ Mol Biol 5, 109-118.

MIDI (1999). Sherlock Microbial Identification System Operating Manual, version 3.0. Newark, DE: MIDI, Inc.

Richard, C. \& Kiredjian, M. (1995). Laboratory Methods for the Identification of Strictly Aerobic Gram-negative Bacilli. Paris: Institut Pasteur.

Rivas, R., Sanchez-Marquez, S., Mateos, P. F., Martinez-Molina, E. \& Velazquez, E. (2005). Martelella mediterranea gen. nov., sp. nov., a novel $\alpha$-proteobacterium isolated from a subterranean saline lake. Int J Syst Evol Microbiol 55, 955-959.

Saitou, N. \& Nei, M. (1987). The neighbor-joining method: a new method for reconstructing phylogenetic trees. Mol Biol Evol 4, 406-425.

Seldin, L. \& Dubnau, D. (1985). Deoxyribonucleic acid homology among Bacillus polymyxa, Bacillus macerans, Bacillus azotofixans, and other nitrogen-fixing Bacillus strains. Int J Syst Bacteriol 35, 151-154.

Skerman, V. B. D. (1967). A Guide to the Identification of the Genera of Bacteria, 2nd edn. Baltimore: Williams \& Wilkins.

Smibert, R. M. \& Krieg, N. R. (1994). Phenotypic characterization. In Methods for General and Molecular Bacteriology, pp. 607-654. Edited by P. Gerhardt, R. G. E. Murray, W. A. Wood \& N. R. Krieg. Washington, DC: American Society for Microbiology.

Swofford, D. L. (1998). Phylogenetic analysis using parsimony (PAUP), version 4. Sunderland, MA: Sinauer Associates.

Wayne, L. G., Brenner, D. J., Colwell, R. R., Grimont, P. A. D., Kandler, O., Krichevsky, M. I., Moore, L. H., Moore, W. E. C., Murray, R. G. E. \& other authors (1987). International Committee on Systematic Bacteriology. Report of the ad hoc committee on reconciliation of approaches to bacterial systematics. Int J Syst Bacteriol 37, 463-464.

Yamaguchi, S. \& Yokoe, M. (2000). A novel protein-deamidating enzyme from Chryseobacterium proteolyticum sp. nov., a newly isolated bacterium from soil. Appl Environ Microbiol 66, 3337-3343. 